ather winds are temporary and accidental. I have paid particular attention to this matter, and I find the usual wind in P'eking is from the south-west, and that other winds do not continue for any length of time. From the $Y$-king it appears that was the same in the most ancient times. It is a fact, attested by the daily record of our observatory here, that the wind does not remain long in any of the four cardinal points, as asserted by the writer above mentioned. Whatever be the causes of the different directions of the wind, it is certain that there are local and temporary, as well as general and universal ones. These can only be discovered by a multitude of observations. Again, why is it that when the wind blows, ice melts first at the water's edge, unless it be that the wind has penetrated the water? A more singular fact still is that there are some winds which are only felt in deep water. The history of the Yuen dynasty affirms that people bathing have become icy cold from a wind of whieh they have beeome suddenly sensible.

Theroual Springs. - Nothing is truer than that mineral waters are very efficacious in curing several maladies. They are better for those past forty years of age than for younger persons. IIot batbs enfeeble and exhaust the latter, because, the blood still possessing all its force, they cause fermentation and perspiration, which disorder and injure the constitution. At a more advanced age, on the other hand, they revivify the blood and clear the bones, nerves, and tissues of the body from the impurities which years bring in their train. Baths should not be taken for some time after eating, and one should be careful of exposure to the air after them. I mention this because everything affecting the health of mankind interests me. It is clear that the heat, smell, taste, and reedicinal virtues of thermal springs are the effects of a mixture of foreign substances in the water. But what are these substances? In what quantity and proportion are they present? This has nat been sufficiently examined. Whenever I meet a mineral spring on my journey I examine it by means of an alombic, and by the alum, sulphur, or metal found there I know its properties. In this respect we must not follow the ancients. They decided superficially by the taste, smell, or colour. I wish these waters were studied better, as then it would be known what diseases they were best suited to cure.

We have not space to give any more of the Emperor's observations. Those translated above are sufficient to show his love of knowledge, and his desire to benefit his subjects by utilising the results of research. Some of his remarks are almost epigrammatic, and with a few of them we will bring this article to a close.

"Lying is the first resource of ignorance; but what shall we do when we do not know the trutb? lie silent."

"I love to admire the manner in which nature confounds our ideas of the greatness of human industry, and baffles all the re sources of our penetration. How difficult it is to admire worthily Is not a small incect, a blade of gra $-s$, more worlhy of our admiration than any production of human hand:?"

"We spoil children by our puerile cares f,or their health. We have, alas! too many wants; why should we increa-c them?"

"Heaven provides for the wants of men according to the places in which they live."

"I prefer to procure a new species of fruit or of grain for my subjects than to build a hundred porcelain towers." 1

"Every one desires health and loves life, but no one practises temperance and frugality. They invent pleasant remedies which they imagine will cause them to dige:t. Eat little, and you will digest much."

"I attribute my good health to the fact that I drink nothing but water, which I distil myself." ?

\section{ON THE EVOLUTION OF ANTLERS IN THE RUMIN'ANTS}

THE development of antlers in the Ruminants to which Sir John Lubbock alluded in his address to the British Association at York, confirms the truth of the doctrine of evolution in so clcar a way that it is well

I For a description of the celebrated porcelain tower of Nanking, sec
Williams's "Midjle Ko Williams's "Middle Kingdom," vol. i. p. 82 . It sh uld be adiled that this remarkable work was destroyed during the occupation of the city by the Taipings, and it may be said if it now, etialm pereunt ruince.

The absence of any syst:m of cirainage in Chinese citics should be remc mbered here. worthy of being laid before the readers of NATURE, although I have already brought it in part before the Geological Society in 1877 (Quart. Journ. Geol. Soc. xxxiv. 4I9), and published it in outline three years later, in my work on "Early Man in Britain, and His Place in the Tertiary Period." The results of an inquiry to which I was led by a systematic study, extending over several years, of the more important collections of fossil mammalia in Britain, France, and Italy, may be summed up as follows :--

In the Middle Stage of the Meiocene the cervine antler consists merely of a simple forked crown (Cervus dicroceros), which increases in size in the Upper Meiocene, although it still remains small and erect, like that of the roe. In Cervws Matheroni it measures $\mathrm{II}^{\circ} 4$ inches, and throws off not more than four tynes, all small (Fig. I).

The deer living in Auvergne in the succeeding or Pleiocene age present us with another stage in the history of antler development. There for the first time we soe antlers of the axis and Rusa type larger and longer and more branching than any antlers were before, and possessing threc or more well-developed tynes (Figs. 2, 3, 4, 5).

Deer of this type abounded in Pleiocene Europe, and I have examined their remains from the Red Crag of Norwich and of Suffolk, from various localiities in Middle and Southern France, from Italy, and even from the little Island of Capri. They belong to the Oriental division of the Cervidx, and their presence in Europe confirms the evidence of the flora brought forward by the Count de Saporta, that the Pleiocene climate of Middle Europe was warm. They have probably disappeared from Europe in corsequence of the lowering of the temperature in the Pleistocene Age, while their descendants have found a congenial home in the warmer regions of Eastern Asia.

In the latest stage of the Pleiocene-the Upper Pleiocene of the Val d'Arno-the Cervus dicranios of Nesti (Fig. 6) presents us with antlers much smaller than those of the Irisb elk, but so complicated as almost to defy description. This animal survived into the succeeding age, and is found in the pre-glacial forest bed of Norfolk, being described by Dr. Falconer under the name of Sedgwick's Deer (C. Sedgrickii).

The Irish elk, moose, stag, reindeer, and fallow deer appear in Europe in the Pleistocene age, all with highly complicated antlers in the adult, and the first possessing the largest antlers as yet known. Of these the Irish elk disappeared in the Prehistoric age after having lived in countless herds in Ireland, while the rest have lived on into our own times in Euro- $\Lambda$ sia, and, with the exception of the last, also in North America.

From this survey it is obvious that the cervine antlers have increased in size and complexity from the MidMciocene to the Pleiostocene age, and that their successive changes are analogous to those which arc observed in the development of antlers in the living deer, which begin with a simple point and increase in number of tynes till their limit of growth be reached. In other words, the devclopment of antlers indicated at successive and widely separated pages of the geological record is the same as that observed in the history of a single living species. It is also obvious that the progressive diminution of size and complexity in the antlers from the present time back into the early Tertiary age shows that we are approaching the zero of antler-development in the MidMeiocene age. I have been unable to meet with a trace of any antler-bearing ruminant in the Lower Meiocenes either of Europe or of the United States.

Vor are we left without direct evidence on this point. The discoveries in the Mid-Meiocene shale of Sansan in the South of France, publisted by Prof. Ed. Lartet in I 839 and $18 ; 1$, and those made in New Mexico, Colorado, and Nebraska, and published by Prof. Cope in 18741877 , present us with a series of antlers in which the burr is conspicuous by its absence. Still more 
recently, in 1878 , similar specimens (Procervalus) have been described by Prof. Gaudry " Les Enchainements," p. 87) from the Mid-Meiocene strata of Thenay in the valley of the Loire. In all these cases the bony prolongation of the frontals - for antler it can hardly be termed-is small, erect, and variously branched, is persistent through life, and probably, as Prof. Cope suggests, was covered, as in the giraffe, and on young growing antlers, with skin.

In some, however, of Prof. Cope's specimens a wellmarked burr is to be seen on some of the tynes (The United States Geogr. Survey, Part II. vol. iv. Palæontology, Pl. lxxx., $3 b, 4 a)$, due perhaps to an accidental strip-

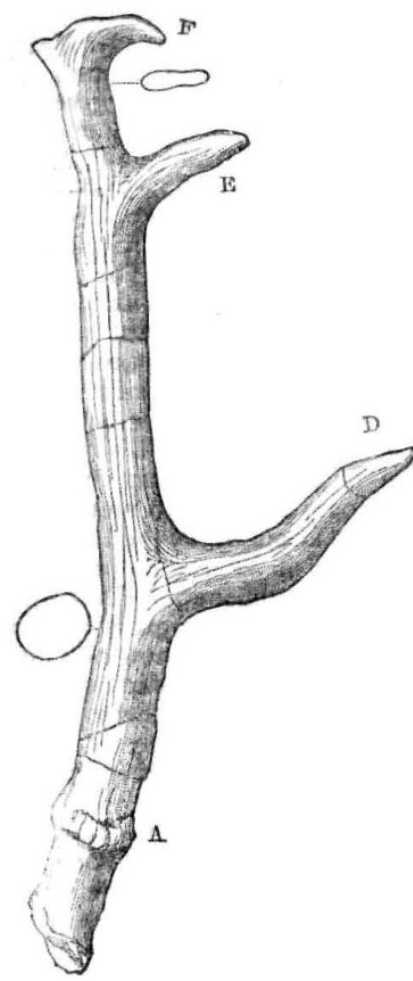

I

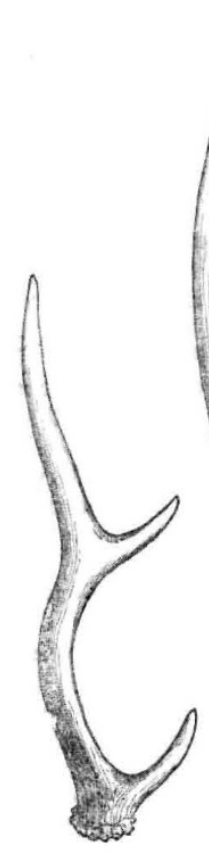

4

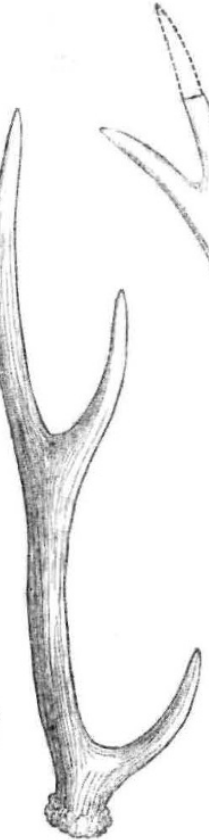

5

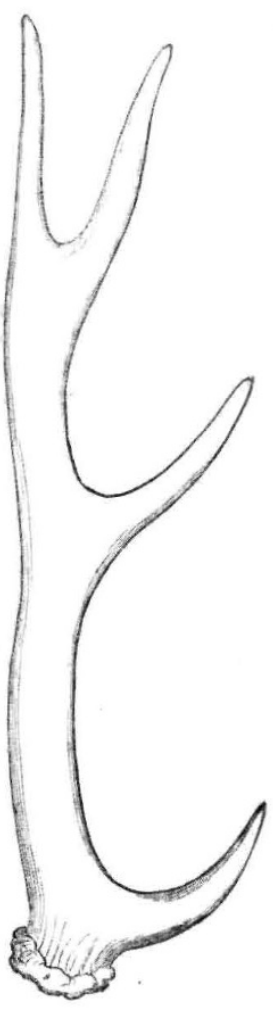

3

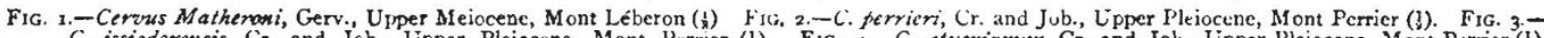
C. issiodorensis, Cr. and Job., Upper Pleiocene, Mont P'errier (1). Fig. 4.-C. etueriarwm, Cr. and Job., Upper I'leiocene, Mont Perrier (b).

in the death of the bony tissue above it. We may there- with the Dicroceros type. The two phases of antler defore conclude that this singular Procervulus type was the velopment in the Mid-Meiocene age in Europe, and prostärting-point of the antlered Ruminants both in the Old bably at the same age in North America, are represented and the New Worlds. In both, moreover, it is associated by living deer, first by the transient condition of the

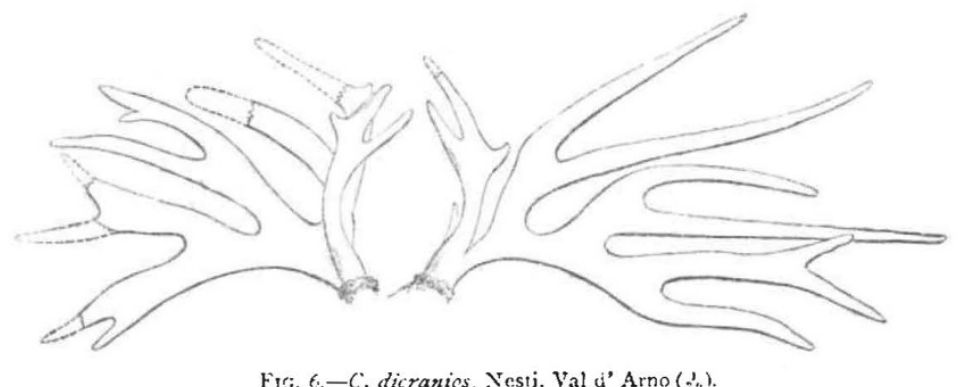

young antler in the velvet, and secondly by the second antler in most species, and by the simple-forked upright antler of the adult muntjac.

The antlers also of the adult fallow deer (C.dama) present variations which can, in my opinion, only be accounted for by the doctrine of evolution. The ancestral form appears in the Pleistocene age in Britain, and is characterised by antlers palmated in front, instead of behind the beam, as in the normal living species, from which I defined it under the name of $C$. Browni, after its discoverer at Clacton in Essex. It occurs also in the gravels of the Thames Valley at Acton. Sir Victor Brooke has pointed out that some three or four specimens out of the vast number of antlers of the living form which he has examined possess 
exactly the same character. Its appearance in the living form may be explained by the hypothesis of a reversion similar to that by which from time to time a horse is born with three toes, due to its descent from a three-toed ancestor. W. BOXD DAWKINS

\section{THE GEOLOGICAL SURVEY OF ITALY}

$A$ MONGST the numerous signs of renewed life which A characterise United Italy, the rapid spread of scientific research must take important rank. In its old homes at the world-famous universities, science, not of ten entirely neglected, is now once more largely cultivated. New Museums are springing up in many of the more important towns, and old ones are everywhere remodelled and enlarged.

Geology has its full share in this scientific revival, as a glance at the annual volumes of the Geological Record will show. The establishment of the Geological Society of Italy, to which we referred a fortnight back, will do much to encourage the study of this science.

The Geological Survey of Italy was established in the year I 868 ; since that date it has gradually developed, and has now accomplished some very important work. The Survey is at present a branch of the Corps of Mining Engineers, but we speak of the service in the phrase best known in England for similar organisations. Since 1870 twelve volumes of the Bollettino del Ro. Comitato Geologico have been published. These contain memoirs of various districts, often well illustrated, by members of the Survey or by other workers whose essays are considered to be worth publishing at the public expense. Probably many memoirs of the latter class will in future find their way into the Geological Society's volume, and the Bollettino be more purely official.

The organisation of the Survey is somewhat peculiar, and exhibits an amount of divided responsibility which can hardly conduce to its success. The service is partly under the control of a committee of eleven members and a secretary. Of this committee Prof. J. Meneghini of Pisa is president. Seven of the members are nominated by the King, chiefly from amongst the professors at the universities. These give their services gratuitously, only the actual travelling expenses being paid by the Government. The remainder are official members, and some of them are in other ways connected with the Survey.

Each member of the committee has a certain amount of influence in the control of the Survey within his own district; he is supposed to be consulted upon all questions relating to classification, naming of fossils, \&c., but the surveyors are really responsible to the official chief of the Survey, M. G. Giordano. Three members of the Scientific Committee take the chief share in the direction. These are Prof. J. Meneghini for Tuscany and Rome; Prof. G. Cemmellaro of Palermo for Sicily; and Prof. J. Capellini of Bologna, whose advice and assistance is always freely at the disposal of the Survey. This dual government might have been desirable in the early stages of the Survey; but now that Italian geology has made such progress, the staff so well trained, and the work so far advanced, it will probably be desirable to reorganise the Survey upon its own basis, giving the sole responsibility to its own official chief.

The surveying staff is part of the Corps of Inspectors of Mines (Ingegneri delle Miniere), the Chief Inspector of which is also the Chief of the Survey. Italy is divided into eight mineral districts-Turin, Milan, Vicenza, Florence, Ancona, Naples, Caltanissetta, Iglesias (Sardinia). The Inspectors of Mines have duties very similar to those of officers holding a like position in England. They visit and report upon mines in cases of accidents, and when any important changes take place in the working of the mines they may be called on for advice. The engineers are chosen from students trained in one of the seven engineering schools of Italy (Turin, Milan, Padua, Bologna, Pisa, Naples, Palermo). They then go for two years to a foreign mining school (Berlin, Freiberg, London, or Paris). Those engineers who are to serve on the Geological Survey Staff receive additional instruction for this purpose. Till now this extra training has generally been obtained from the Geological Survey of England, so that we may regard the Italian Survey as in a certain sense related to our own. Of the officers thus trained in England we may mention $M$. Anselmo, L. Baldacci, L. Mazzetti, R. Travaglia, De Ferrari, and E. Cortese ; to the last named of these we are indebted for much information here given.

The basis of every geological survey must be a good topographical map. The Austrians published a map of a great part of Italy on the scale of $1: 75,000$; this however is not satisfactory. An entirely new topographical survey is now in progress; commenced in Sicily in 1862, it is gradually advancing to the north. The general map of Italy is on the scale of I : 50,000, with contour lines at every ro metres. The more important mineral districts are published on the scale of $I: 25,000$, with contour lines at every 5 metres; a very beautiful map of Rome and the surrounding country is now published on the larger scale, as also are Sicily and parts of the N.W. Apennines. There is a smaller map, on the scale of I : 100,000, with contours at every 50 metres.

The small sum voted annually by the Italian Parliament has hitherto been spent in surveying only, and none of the maps have yet been published. They were however all exhibited at the Geological Congress at Bologna. It is expected that a larger grant will now be made, and the Survey be placed on a more satisfactory footing. The Central Survey office at Rome, hitherto lodged in the Piazza S. Pietro in Vincoli, will shortly be transferred to the handsome buildings lately erected for the Ministry of Agriculture, Industry, and Commerce.

The whole of the Island of Sicily has been geologically surveyed on the largest scale. This district is of commercial importance from its great yield of sulphur, amounting to 250,000 tons per year. The entire map of Sicily on the scale of 1 : 50,000 was exhibited at Bologna; this is a very beautiful work, and will be of great service to all students of that most interesting region. The Apennines north of Pisa are also surveyed on the scale of $I: 25,000$. This district is of great importance from the marble quarries of Carrara, Massa, \&c., the yield of which is I 50,000 tons per year. Great uncertainty has long been felt as to the geological age of the Carrara marble; it contains no fossils, and its exact relation to adjacent formations has hitherto been doubtful. It has at various times been referred to many different geological horizons; but now the geological surveyors seem definitely to have fixed its position in the Trias. The mineral districts of Sardinia and the Campagna of Rome have also been surveyed on the scale of I : 25,000 .

The complete geological survey of a country is a work of some time, and many years must elapse before that of Italy is finished and its maps published. In the meantime the Survey has done a most useful work in preparing a general geological map of Italy on the scale of 1 : 500,000 . For this purpose all previously published information has been utilised; the geological notices scattered through various scientific journals, Italian and foreign, have been collected and arranged by M. Giordano and his colleagues. The numerous blanks have been filled up by special researches; and the result is a valuable and beautiful map, which will shortly be published. It was desired to issue a reduction of this on the scale of $I: I, \infty \infty,, \infty)$, but as no topographical map on this scale exists, a French map was adopted, engraved, on the scale of I : I, I I I, I I I (or I decim. to a degree). This map was corrected where necessary, and was published in time for the meeting of the Congress at Bologna. The map is issued in two 